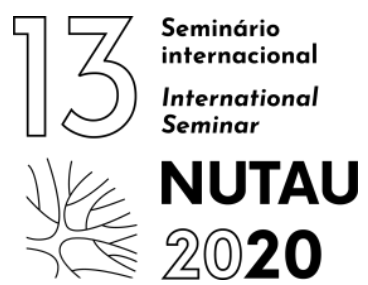

\title{
Resíduos da arborização urbana Produtos de madeira sólida
}

\author{
Sergio Brazolin \\ Laboratório de Árvores, Madeiras e Móveis - Instituto de Pesquisas Tecnológicas de São Paulo \\ Doutor em Recursos Florestais, brazolin@ipt.br
}

\section{RESUMO}

Os princípios de coleta (localidade), separação e de volume são condições mínimas para se viabilizar o uso do resíduo com origem nas podas de galhos e na supressão de árvores da floresta urbana para a fabricação de produtos de madeira, seja em uma iniciativa do gestor público ou qualquer outra atividade empreendedora. Para este tipo de resíduo biológico, também há uma carência de informações tecnológicas, pois as espécies de árvores comumente utilizadas na arborização urbana, não representam madeiras comerciais na construção civil. Além disso, é um resíduo proveniente de diferentes partes da árvore (galhos, tronco e raízes) que podem apresentar distintas propriedades físicas, mecânicas, sensoriais e de resistência aos organismos xilófagos, como os fungos apodrecedores e insetos. Considerando essas condições, temos a proposta de discutir a importância da caracterização tecnológica deste resíduo para a melhor definição de uso como produto de madeira sólida (estrutural, móveis, decoração, artesanato, entre outros) e as boas práticas no seu processamento industrial, com foco na secagem e armazenamento adequados, que são nevrálgicas para se garantir a qualidade desejada e mercado almejado.

Palavras-chave: resíduo, madeira, poda, supressão de árvores.

\begin{abstract}
The principles of collection (location), separation and volume are minimum conditions to enable the use of the waste originating from the pruning of branches and the suppression of trees in the urban forest for the manufacture of wood products, either in an initiative of the manager public or any other entrepreneurial activity. For this type of biological waste, there is also a lack of technological information, since the tree species commonly used in urban afforestation do not represent commercial wood in civil construction. In addition, it is a residue from different parts of the tree (branches, trunk and roots) that may have different physical, mechanical, sensory properties and resistance to xylophagous organisms, such as rotting fungi and insects. Considering these conditions, we have the proposal to discuss the importance of the technological characterization of this residue for the best definition of use as a solid wood product (structural, furniture, decoration, handicrafts, among others) and the good practices in its industrial processing, focusing in adequate drying and storage, which are essential to ensure the desired quality and the desired market.
\end{abstract}

Keywords: waste, wood, pruning, tree suppression. 